\title{
Lignin and Cellulose Content of Fermented Rice Straw with Aspergillus niger (van Tieghem) and Trichoderma mutan AA1
}

\author{
Sri Sukaryani ${ }^{1, *}$, Engkus Ainul Yakin ${ }^{2}$, Yos Wahyu Harinta ${ }^{2}$, Zane Vincēviča-Gaile ${ }^{3}$, \\ and Endang Dwi Purbajanti ${ }^{4}$. \\ ${ }^{1}$ Department of Animal Husbandry, Faculty of Agriculture, Veteran Bangun Nusantara University, \\ J1. Letjen Sujono Humardani No. 1, Sukoharjo 57521, Central Java, Indonesia \\ ${ }^{2}$ Department of Agribusiness, Faculty of Agriculture, Veteran Bangun Nusantara University, \\ Jl. Letjen Sujono Humardani No. 1, Sukoharjo 57521, Central Java, Indonesia \\ ${ }^{3}$ Department of Environmental Science, University of Latvia, Jelgavas Street 1, Room 302, \\ Riga LV-1004, Latvia \\ ${ }^{4}$ Department of Agriculture, Faculty of Animal Science and Agriculture, Diponegoro University, \\ Jl. Prof. Sudarto No.13, Tembalang, Semarang 50275, Central Java, Indonesia
}

\begin{abstract}
The rice straw has potential to be used as an alternative ruminant feed. However, it has limiting factors i.e low crude protein, high crude fiber, lignin, cellulose, and silica content. To overcome the limiting factors, immersion in a solution of alkaline (lime) or fermentation by using inoculum microbial cellulolytic and lignocellulolytic (Trichoderma mutan AAl and Aspergillus niger.). The research method was experimental, with four treatments and repeated five times. Completely randomized design was used and if there are differences among treatments a further test with DMRT was carried out (level $1 \%$ and $5 \%$ ). These treatments were T0: The rice straw without $\mathrm{t}$ fermentation; $\mathrm{T} 1$ : Fermented with A. niger; T2: Fermented with T. mutan AA1; T3: Fermented with a combination A. niger and T. mutan AA1. The results showed that the rice straw fermented with $A$. niger and $T$. mutants AA1 very significantly increased the cellulose and decreased lignin content. The highest cellulose reached on T3 (20.297 \%) followed by T2 (18.191\%), T1 (17.712\%) and T0 $(16.747 \%)$, respectively. While the lowest content of lignin reached on T3 $(14.793 \%)$, followed T2 $(26.063 \%), \quad$ T1 $(26.421 \%)$ and T0 (38.164 \%).
\end{abstract}

Keywords: Fermentation, fungus, increase feed quality, inoculum, waste to feed

\section{Introduction}

The rice production in Indonesia is abundant, namely in 2017, the production of dry rice around $81382451 \times 10^{6} \mathrm{t}$. Based on the calculations, each of ton dry grain will produce the rice straw with equivalent weight. Therefore, rice straw availability enormous potential in Indonesia not yet utilized optimally for ruminant feed. The area of the rice straw is quite

\footnotetext{
* Corresponding author: srisukaryani@gmail.com
} 
wide and spread, proper management is needed. But rice straw as feed has a limiting factor i.e. low crude protein, high crude fiber, lignin, and cellulose content [1-3]. Rice straw contains crude protein about $3.80 \%$ [4] and fiber around $39.81 \%$, lignin around $15 \%$ [5] and silica about $10 \%$ to $15 \%[6,7]$. The high fiber content will delay the hydrolysis process by fermentatation, i.e. microbes enzyme in rumen resulting lower absorption [8-10]. Previous study Sukaryani [11] showed that $4 \mathrm{~d}$ fermentations of rice straw with MA-11 started by submersion in alkaline solution improved the crude protein from $5.22 \%$ to $8.23 \%$ and decreased the crude fiber from $54.24 \%$ to $38.83 \%$. While the fermentation of rice straw from $2 \mathrm{~d}$ to $6 \mathrm{~d}$ by MA-11 starting with submersion of rice straw in the alkaline solution, reducing NDF from $69.22 \%$ to $62.20 \%$ and ADF from $50.21 \%$ become $36.93 \%$ [12].

To overcome the limiting factors of rice straw, an alternative effort that can be done are to provide the treatment of immersion in a solution of alkaline (lime), and the process of the rice straw fermentation by using inoculum microbial cellulolytic and lignocellulolytic (Trichoderma sp. and Aspergillus sp.). Trichoderma sp producing the extracellular prolific protein [15] and it has the ability to produce the enzyme to degradation the cellulose [14, 15]. Similarly, A. niger produce some enzymes such as enzyme cellulolytic [14, 15], amylase [18], and glucoamylase [19].

This research aimed to assess the content of lignin and cellulose in fermented rice straw with A. niger and $T$.mutants AA1.

\section{Materials and methods}

The study was conducted in Laboratory Agriculture Faculty Veteran Bangun Nusantara University of Sukoharjo, Central Java, Indonesia.

The material used in the form of rice straw obtained from paddy fields in Karanganyar district, Central Java, Indonesia microbial (A. niger and Trichoderma mutant AA1), molasses, urea, lime, and water.

The tool used in this study was a bucket and place of manufacture fermentation jar, chopper, blender, and laboratory devices for content analysis lignin and cellulose.

This research uses a design completely randomized design with the pattern of four kinds of treatments and five replications. The treatments are:

T0: The rice straw without fermentation

T1: The rice straw fermented with A. niger

T2: The rice straw fermented with $T$. mutant AA1

T3: The rice straw fermented with a combination T. mutans AA1 dan A. niger

Before fermentation, rice straw was submersed in a lime solution for $2 \mathrm{~d}$.

The variables observed in this study werelignin and cellulose content. The data were analyzed statistically using Analysis of Variance (ANOVA) and followed by Duncan's Multiple Range Test (DMRT).

\section{Result and discussions}

\subsection{Lignin content (\%)}

The results showed that the lignin content of fermented rice straw with A. niger, T. mutant AA1, and the combination were presented in Table 1. 
Table 1. Lignin content of rice straw fermented with AA1 mutan Trichoderma and A. niger

\begin{tabular}{|c|c|c|c|c|}
\hline \multirow{2}{*}{ The replication } & \multicolumn{4}{|c|}{ Lignin content (\%) } \\
\cline { 2 - 5 } & $\mathbf{T 0}$ & $\mathbf{T 1}$ & $\mathbf{T 2}$ & $\mathbf{T 3}$ \\
\hline 1 & 37.422 & 25.629 & 26.915 & 14.401 \\
\hline 2 & 37.779 & 27.184 & 25.780 & 15.989 \\
\hline 3 & 38.638 & 26.086 & 27.601 & 14.425 \\
\hline 4 & 37.234 & 26.899 & 24.161 & 13.451 \\
\hline 5 & 39.745 & 26.308 & 25.860 & 15.701 \\
\hline Average & $38.164^{\mathrm{a}}$ & $26.421^{\mathrm{b}}$ & $26.063^{\mathrm{b}}$ & $14.793^{\mathrm{c}}$ \\
\hline
\end{tabular}

Note: Different superscripts on the same line show highly significant $(\mathrm{p}<0.01)$.

Based on Table 1, lignin content in fermented straw with A. niger or T. mutant AA1 individually or in combination degrade lignin highly significant. After further tested by DMRT showed, the lowest lignin content was reached by T3 $(14.793 \%)$, followed by T2 $(26.063 \%), \mathrm{T} 1(26.421 \%)$ and T0 $(38.164 \%)$. Treatment T1 and T2 showed lignin content was not significantly different. Visually, the lignin in T2 tends to be lower than T1. This indicates that the Trichoderma has higher ability to degrade lignocellulose than the A. niger. The content of lignin in $\mathrm{T} 3$ is lower significantly than $\mathrm{T} 0, \mathrm{~T} 1$, and $\mathrm{T} 2$, this phenomenon indicates that both types of fungus can grow and thrive in an atmosphere of the same media and mutual synergy to meet the needs. During the fermentation, A. niger and $T$. mutant AA1 produced lignolytic enzyme that degrade lignocellulose, wrapping the cell wall binding micro fibril cellulose and hemicellulose apart, then the lignin in the cell wall that prevents the cellulose down. This result in accordance to Agustini and Efiyanti [20] that the biological treatment of the substrates Albiziachinensis, sawdust and palm leaf midrib with fungi FB1 MD-14 isolate lower the lignin content. Likewise, some studies stated fermentation with microbes can degrade lignin to improve the quality and palatability of feed [21-24].

\subsection{Cellulose content}

The research data from cellulose content listed in Table 2.

Table 2. Cellulose content of rice straw fermented with T. mutant AA1 and A. niger

\begin{tabular}{|c|c|c|c|c|}
\hline \multirow{2}{*}{ The replication } & \multicolumn{4}{|c|}{ Cellulose content (\%) } \\
\cline { 2 - 5 } & $\mathrm{T} 0$ & $\mathrm{~T} 1$ & $\mathrm{~T} 2$ & $\mathrm{~T} 3$ \\
\hline 1 & 16.709 & 17.408 & 17.860 & 20705 \\
\hline 2 & 17.812 & 17.821 & 18.030 & 19.142 \\
\hline 3 & 16.012 & 17.728 & 18.523 & 20.225 \\
\hline 4 & 16.725 & 17.649 & 18.170 & 21.046 \\
\hline 5 & 16.479 & 17.957 & 18.373 & $20.369^{\mathrm{c}}$ \\
\hline Average & $16.747^{\mathrm{a}}$ & $17.712^{\mathrm{b}}$ & $18.191^{\mathrm{b}}$ & $20.297^{\mathrm{c}}$ \\
\hline
\end{tabular}

Note: Different superscripts on the same line show very significantly different $(p<0.01)$

Result showed that the treatment of fermentation using A. niger and T. mutant AA1 very significantly improved the content of cellulose. This is might due to the activity of enzyme produce by cellulolytic has degraded lignocellulose. Cellulose become available for degrading and absorption. According to Prihartini, et al. [25], cellulose content in fermented rice straw tends to improve. In addition by Agustini and Efiyanti [20] that 
biological treatment that applied to the substrate A.chinensis wood, sawdust, and palm leaf midrib with fungi MD-14 FB1 isolate tend to improve cellulose. After being further tested by DMRT, the highest cellulose content was by T3 $(20.297 \%)$ and the lowest in T0 $(16.747 \%)$.

\section{Conclusions}

The results of the research can be concluded that:

i. Fermented of the rice straw using A. niger and T. mutant AA1 with monoculture and a combination of both decreased the lignin and increased cellulose content.

ii. The lowest lignin and highest cellulose content in fermented rice straw occurred in a combination of $A$. niger and T. mutant AA1 inoculum.

iii. Fermentation rice straw with A. niger and T. mutant AA1 in monoculture produced not different lignin and cellulose content.

\section{Suggestion}

Further research on fermentation can be done by using a combination of fungus $A$. niger and T. mutant AA1 to be applied on others agricultural waste.

\section{References}

1. M. Bata. Agripet. 8,2:15-20(2008). [in Bahasa Indonesia]. https://doi.org/10.17969/agripet.v8i2.610

2. D. Aquino, A. Del Barrio, N. X. Trach, N. T. Hai, D. N. Khang, N. T. Toan, et al, in Sustainable Rice Straw Management, Springer, Cham, (2020).p.111-129. https://doi.org/10.1007/978-3-030-32373-8

3. N. Ali, Suhartina, A. Muktiani, E. Pangestu, IOP Conference Series: Earth and Environmental Science, 492:012028(2020). https://doi.org/10.1088/1755-1315/492/1/012028 or http://dx.doi.org/10.1088/17551315/492/1/012028

4. S. Ahmed, M. J. Khan, M. Shahjalal, K. M. S. Islam, Asian-Australasian J Anim. Sci, 15,4:522-527(2002). https://doi.org/10.5713/ajas.2002.522

5. G. Gou, W. Wei, M. Jiang, S. Zhang, T. Lu, X. Xie, et al, Pulp Paper Processing, 6:133-154(2018). $\quad \underline{\text { http://dx.doi.org/10.5772/intechopen.79014 or }}$ https://www.researchgate.net/publication/328083802_Environmentally_Friendly_Met hod_for_the_Separation_of_Cellulose_from_Steam-

Exploded_Rice_Straw_and_Its_High-

Value_Applications/link/5bb6c03aa6fdcc9552d3d8e9/download

6. N. Reddy, Y. Yang, J. agric. food chem. 54,21:8077-8081(2006). https://doi.org/10.1021/jf0617723

7. M. Bhattacharya, M. K. Mandal, J. Clean. Prod. 186:241-252(2018). https://doi.org/10.1016/j.jclepro.2018.03.099.

8. X. Tang, G.O. Tayo, Z.L. Tan, Z.H. Sun, L.X. Shen, C.S. Zhou, et al. J. Anim. Sci. 86,5:1164-1172(2008). https://doi.org/10.2527/jas.2007-0438

9. A. Wahyudi, D. Pamungkas, R. H. Setyobudi, L. Hendraningsih, Z. Vincēviča-Gaile. Proc. Pakistan Acad. Sci. part B,54,1:41-45(2017). https://www.paspk.org/wp-content/uploads/2017/03/Organic-Acid-and-NutrientComposition-of-Lactic-Acid.pdf 
10. A. Wahyudi, L. Hendraningsih, Sutawi, R.H. Setyobudi, M. Mel. IOP Conf. Series: Earth and Environmental Science. 293:01200(2019). doi:10.1088/1755-1315/293/1/012007

11. S. Sukaryani, Agrisaintifika Jurnal Ilmu-Ilmu Pertanian. 2,2:160-164(2018).[in Bahasa Indonesia] https://agrisaintifika-fpunivet.ac.id/ojs/index.php/AGRISAINTIFIKA/article/view/108

12. S. Sukaryani, Jurnal Ilmiah Teknosains, 2,2:91-94(2016). [in Bahasa Indoensia] https://doi.org/10.26877/jitek.v2i2/Nov.1198 http://journal.upgris.ac.id/index.php/JITEK/article/view/1198/1060

13. A. Rodriguez-Iglesias, M. Schmoll, Scientific Reports, 9,1:10995(2019). https://doi.org/10.1038/s41598-019-47421-z

14. G. E. Harman, C. R. Howell, A. Viterbo, I. Chet, M. Lorito, Nature reviews microbiology, 2:43-56(2004). https://doi.org/10.1038/nrmicro797

15. S. Chakraborty, R. Gupta, K. K. Jain, R. C. Kuhad, Bioprocess Biosyst. Eng., 39:1659-1670(2016). https://doi.org/10.1007/s00449-016-1641-6

16. T. C. D. Santos, G. Abreu Filho, A. R. D. Brito, A. J. V. Pires, R. C. F. Bonomo, M. Franco, Revista Caatinga, 29,1:223-233(2016). https://doi.org/10.1590/198321252016v29n126rc

17. S. Vidmar, V. Turk, I. Kregar, Appl. Microbiol. Biotechnol. 20:326-330 (1984). https://doi.org/10.1007/BF00270594

18. K. Mihajlovski, M. Rajilić-Stojanović and S. Dimitrijević-Branković, Renew. Energ. 152:627-633(2020). https://doi.org/10.1016/j.renene.2020.01.101

19. K. Ratanaphadit, K. Kaewjan and S. Palakas, Asia-Pacific J. Sci. Technol. 15,9:833842(2010). https://so01.tci-thaijo.org/index.php/APST/article/view/84065

20. L. Agustini, L. Efiyanti, Jurnal Penelitian Hasil Hutan, 33,1:69-80(2015). [in Bahasa Indonesia]. https://doi.org/10.20886/jphh.2015.33.1.69-80 or http://ejournal.fordamof.org/ejournal-litbang/index.php/JPHH/article/view/640/622

21. S. Rulianah, H. Profiyanty, Y. Maryanty, B. Irawan, Adv. Sci. Lett. 23,6:56665668(2017). https://doi.org/10.1166/asl.2017.8796

22. B.-S. Xing, Y. Han, S. Cao, J. Wen, K. Zhang, H. Yuan, X. C. Wang, Chemosphere, 250:126104(2020). https://doi.org/10.1016/j.chemosphere.2020.126104 or http://www.sciencedirect.com/science/article/pii/S0045653520302976

23. M. U. Khan, B. K. Ahring, Biomass Bioenergy, 128:105325(2019). https://doi.org/10.1016/j.biombioe.2019.105325 http://www.sciencedirect.com/science/article/pii/S0961953419302740

24. M. Asgher, A. Wahab, M. Bilal, H. M. Nasir Iqbal, Biocatal. Agric. Biotechnol. 6:195-201(2016). $\quad$ https://doi.org/10.1016/j.bcab.2016.04.003 http://www.sciencedirect.com/science/article/pii/S1878818116300597

25. I. Prihartini, S. Soebarinoto, S. Chuzaemi, M. Winugroho, Anim. Prod. 11,1:1-7(2011). [in Bahasa Indonesia]. http://animalproduction.net/index.php/JAP/article/view/215/203 